\title{
MAINTAINING THE GOOD IMAGE OF A PUBLIC FIGURE THROUGH THE USE OF REPUTATION MARKETING
}

\author{
Anathasia Citra \\ Communication Studies, School of Humanities, President University \\ Jababeka Education Park \\ Email anathasiacitra@gmail.com
}

\begin{abstract}
This study aims to look at the application of the application of Reputation Marketing by a Public Figure in maintaining a good image. How does the use of Reputation Marketing in the entertainment industry can affect the continuity of the career of a Public Figure. The careers of a Public Figure who work in the entertainment industry is very vulnerable, if marketing strategies and maintain a good self image are not implemented. This study takes Hilbram Dunar as the subject. He works as a television host, radio host, MC, entertainer and author who began his career in 1996, while maintaining good image to date. With the concept of Reputation Marketing, author examined his personal branding, personal and social life to his choice of words and topics in social media. This research will contribute ideas to the study of communication with the subject about the image, personal branding, reputation marketing and reputation marketing in the era of internet, and provide practical ideas for public figures who work in the entertainment industry. This research is a descriptive study with a qualitative approach. The results of this study found that the application of Reputation Marketing is very appropriate to maintain a good image of a Public Figure who works in the entertainment industry. With the development of technology, especially the new media such as the various social media such as twitter and path, a public figure must have his own positioning of the image that he wants to convey to the public and must maintain consistency. In addition, there are things that must be avoided in order to maintain reputation. Reputation is important for the career of a Public Figure and good image is not easy to maintain. The application of Reputation Marketing for Public Figure has the same function like a product, which is for generating profit. A good image of a Public Figure becomes a commodity which will have an impact on the sustainability of his career.
\end{abstract}

Keywords: Reputation, Image, Reputation Marketing

\begin{abstract}
ABSTRAK. Penelitian ini bertujuan untuk melihat penerapan Reputation Marketing yang diterapkan oleh seorang Public Figure dalam mempertahankan citra baiknya. Bagaimana penggunaan Reputation Marketing di industri hiburan khususnya dapat berpengaruh terhadap kelanggengan karir seorang Public Figure, khususnya yang bekerja di dunia hiburan. Public Figure yang bekerja di dunia hiburan sangat rentan karirnya jika tidak menerapkan strategi pemasaran diri yang baik dan mempertahankan citra baiknya. Subjek Penelitian ini adalah Hilbram Dunar seseorang Public Figure yang bekerja sebagai pembawa acara televisi, penyiar radio, MC, entertainer dan Penulis buku yang memulai karirnya dari tahun 1996 dengan tetap menjaga citra baiknya sampai saat ini. Dengan konsep Reputation Marketing, peneliti mengkaji strategi yang diterapkan oleh subjek penelitian, mulai dari personal branding, kehidupan pribadi dan sosial hingga pemilihan kata dan topik dalam media sosialnya. Penelitian ini akan memberikan sumbangan pemikiran bagi studi tentang Komunikasi khususnya mengenai citra, personal branding, reputation marketing dan reputation marketing di era internet dan memberikan sumbangan pemikiran praktis untuk pribadi terutama public figure yang bekerja di industri hiburan. Penelitian ini merupakan penelitian deskriptif dengan pendekatan kualitatif. Hasil penelitian ini ditemukan bahwa penerapan Reputation Marketing sangat sesuai diterapkan untuk pribadi khususnya dalam menjaga citra baik sebagai seorang Public Figure yang bekerja di industri hiburan. Dengan makin cepatnya perkembangan teknologi terutama media baru seperti berbagai social media seperti twitter, dan path, seorang public figure harus punya positioning sendiri mengenai citra apa yang ingin dia tampilkan ke publik dan harus menjaga konsistensinya. Selain itu harus ada hal hal yang dihindari untuk menjaga reputasi. Reputasi disini penting artinya untuk karir seorang Public Figure dan citra baik bukanlah hal mudah untuk dijaga. Penerapan Reputation Marketing untuk Public Figure sama fungsinya bagai sebuah produk, yaitu untuk sesuatu yang menghasilkan profit. Public Figure menjadi sebuah komoditas dimana citra baiknya berdampak pada keberlanjutan karirnya.
\end{abstract}

Kata Kunci : Reputasi, Citra, Reputation Marketing 


\section{INTRODUCTION}

The growth of the entertainment industry makes competition become fiercer, especially for actors in the industry in terms of capturing public attention. The entertainment industry is filled with on-screen actors such as actors, musicians, presenters and so on, whom author calls as the public figures. A public figure is an individual widely known in the society because of his profession. The term public figure - in Indonesian contex - can be categorized into two: celebrity and state official. This study highlights celebrities as the public figures.

The rapid growth in the entertainment industry has led some public figures to benefiting from their peak times, being praised by people, becoming role models, starring in commercials and also becoming endorsers for different products. However, such peak may disappear in an instant once a public figure can no longer maintain his good reputation. A public figure cannot detach himself from being a product, selling his ability and charm in the respected field. The skills of a public figure, being the commodity of the entertainment industry, such as singing, acting, presenting, being comedic, modeling and so forth, are the foundations of his career and revenues as well as his existence as a known public figure to the public.

The celebrity is an industry of imagebuilding, in which public figures display their images to the public and that in turns becomes their selling point. The images delivered by public figures such as when they perform in a TV show, when they put on their best performance to convey charisma and power, or when they deliver speeches deemed wise to impress the public. In addition, their backgrounds such as family, education and so on, also attract the attention of the public.

The success measure of public figures is still yet to be defined, whether it is based on their income, quality of work or consistency as public figures. As figures in the entertainment industry, their existensial beings are automatically put under the surveillance of the public. The public becomes interested in what they do, what their hobbies are, their love lives, and even what they eat. In their peak of their fame and success, one thing or another often cause them to slip and that costs them their images as public figures.

In the process of building their images, there are matters that should be focused on by a public figure such as knowing what the public wants, likes and dislikes in general. Staying current with the patterns emerging in the society, as well as learning to build positive self image will make it more effective for the public figure to make his move.
Today, the media is the main key to the industry driven by images. The media can make someone rise to become a star instantly and can also cause devastation to someone. According to Eduard Depari, a seasoned public relations practitioner, most people do not realize that image and reputation are not isolated from one to another. Image is just a tool. Reputation is what people judge (Hana, 2013).

This study was designed to develop a measure of a public figure's reputation and to identify the key dimension that evaluates different components of such reputation of a public figure comprising personality, relationships, skills, personal life management, as well and use of social media as a tool to shape and maintain reputation.

\section{FRAMEWORK}

Every study requires clarity in its underlying rationale in order to solve or highlight the given problem, which is why theoretical framework is structured (Nawawi, 1995). Theoretical framework is the underlying rationale that describes the angle taken by the researcher to study the problem (Kriyantono, 2006). This study adopted some concepts from previous studies and literatures on image, personal branding, reputation marketing, and social media.

\section{Definition of Image}

According to Lawrence L Steinmetz, the term image means a reflection or reproduction of self identity of an individual, object or organization (Sutojo, 2004). Author focuses on the image of a public figure, which is defined as the perception perceived by the public through knowledge and experience towards the public figure. To a public figure, an image is defined as perception of the public towards his self image. Such perception of the public is a manifestation of what they see on the public figure when he appears on TV, what they heard from the news, or when they see him live in a public space, for instance. If the image is deemed 'appropriate' by the public, it will boost and improve his career as an entertainer.

Image is the goal, a form of reputation and achievement that any public figure wants to accomplish. Although image is abstract and cannot be systematically measured, its manifestation is present. The success of a public figure in building his image is influenced by a number of factors such as accurate grasp of his target audience or market, performance, social circles, self representation in the media, and how he interacts on social media.

\section{Personal Branding}

Personal branding is a means to illustrate and communicate what makes you different and special. It is when you understand your attributes, power, 
skills and worth, then use them to differentiate yourself from competitors (Arruda, $2002: 6$ ).

Personal branding describes the process in which an individual or professional differentiate himself and step out of the group by identifying and articulating his unique value proposition, be it personal or professional, and then display them in different platforms with a consistent message in order to achieve certain goals. This way, individuals can get more recognition of expertise in their fields, build reputation and credibility, advance their careers, and build confidence (Schawbel,2009: 4).

Today, branding has transformed differently and become not just a tool that is applicable to companies developing their brands, but also a tool that is applicable to you in order to develop your own brand. This is what is called personal branding, and it matters for professional success (Arruda, 2002).

According to I.D.H Sheperd, personal branding has now become an industry as individuals are encouraged and advised to maket and shape their personal brand. Sheperd showed that personal branding applies the same basic principles as product marketing and branding by companies. Although the applications of personal branding are relatively new, it has been practiced globally by public figures in the film, sport, and music industries, and also leaders in the corporate and politics in the last decade (Shephard, 2005)

Celebrities are depicted as 'a product' by their managers for successful campaigns with which their names are associated. For that reason, every public appearance and greeting is of importance because their images are all dependent on this (Koku, 1995).

"A personal brand is like a piece of classical music on the page, it may be finished, but it's not fully realized until it reaches the ears of audience through performance” (Montoya,2002: 15).

\section{Reputation Marketing}

First impression is a new step to creating and defining reputation. People literally judge a book by its cover. Most of good books are left unread because of unattractive cover or poor placing in the shelves, and many good products are not successful simply because they have 'flat' appearances. Those who do not put an emphasis on look, sound and overall impression of the product disrespect the market. Think of reputation as a dress code, something that is defined, inflexible and simbolic (Marconi, 2001: 63-64).

Nowadays, as the media and communication technology grow more dynamic, it encourages a shift from building an image of a public figure in a short-term perspective to a long-term one, so that it becomes sustainable and shapes up into a reputation. Globalization has made anything more worldwide, dynamic and multidimensional, enabled vast, fast and easy access to information thanks to the internet. Such developments in communication encourage a focus on a more sustainable concept of image and reputation.

The term reputation is usually not misunderstood. The Webster's New World dictionary defines reputation as (1) what is shown to a person or the public, community and so on, (2) what brings benefit (e.g. loss of representation of someone), or (3) what differentiates. Nurturing, protecting, or exploiting reputation can be a difficult art; skills in reputation marketing often determine the success or the failure of a company, a product, or a brand. This is because marketing, in a wider sense, is all about positioning, packaging, pricing and promoting, and reputation management is part of the differentiator in the marketing process (Marconi, 2001:2).

The way you look or present yourself shapes your image. Image, from time to time builds reputation. You position yourself in the market through campaign, public relation, package design, unique selling point, presentation, performance and quality of service.

\section{Tell People who you are \\ Tell them what you do \\ Tell them why they should care}

Marketing is about timing, place and program used to enhance quality, optimize costs, maximize value, and exhibit best and most unique characteristics that differentiate you from others. It makes the public wants to connect with you and know more about you (Marconi, 2001:70).

\section{Reputation Marketing in the Age of the Internet}

In the late ' 90 s, after a quarter century of a limited use by academic researchers and the military, the internet quickly became the heart of marketing activities. It soon was labelled 'the new media', although it went beyond that. The internet became a new place to showcase for corporate or personal use.

Social media are the media for social interactions, platforms that transcend beyond social communication. It is powered, accessed and measured by the use of digital communication technologies. Social media has substantially altered the way to communicate among organizations, individuals and the public. Social media use mobile and web technologies to create highly interactive platforms in which individuals and the public are able to share, create, discuss, and modify usergenerated content. Considering the extraordinary exposure of social media in the popular news media, 
we are in the midst of a completely new communication landscape. (Kietzmann, Hermkenss, McCarthy, dan Silvestre, 2011)

The emergence of social media also affected the image-driven industry including the entertainment industry. Public figures who use social media accessed by their audiences can bolster certain images, which leads to building reputations.

One of the most beneficial ways for public figures to use social media is to build their brands to be more connected with their fans. Twitter or Instagram provides a public figure with a relatively safer platform to communicate with their fans, although not all interactions are positive; some celebrities involve themselves in a social media war, such as twitwar on Twitter, with their haters. Social media is ideal for self promotion with the use of daily tweets, status updates, or photos, so that existency as a celebrity is well-maintained in the eyes of the public. Many of the celebrities use different platforms at once, so that their fans can stay current. They share their activities, plans, and information about future projects to keep the fans informed. In the age of the internet and social media, sometimes when people stop talking about a certain public figure, he may have to start worrying (Kohen, 2013).

\section{RESEARCH METHODOLOGY}

This study applies the qualitative approach. Author views the issues being highlighted in this study from a descriptive angle. The data collected is in the form of words instead of numbers, as an application of the qualitative method. In addition, all the gathered data may be key to what has been researched prior to the study. This study report, thus, will refer to the given data to illustrate the findings from previous research.

To a researcher who uses the qualitative method, there is just not only one reality. Every researcher creates the reality as part of the research process, which is subjective in nature and only under the reference of the researcher. The researcher observes the entire process as a holistic and undivided reality (Dominick, Wimmer, 1991; 139).

The descriptive angle relies on observation and naturalistic setting. The naturalistic setting means that the researcher goes directly to the field. He does not try to manipulate the variables. Since the researcher's presence may affect the reactive measures, he minimizes such impact. The researcher acts as an observer. He only makes a categorization of behaviors, observes signs, takes notes for matters such as interviews, field notes, photos, videotapes, personal documentations, records or memos. In such report-writing setting, the researcher analyses the rich data and connects as much as possible with the data's original form(Rahmat, 1999; 25).
Author takes Hilbram Dunar, a public figure in the entertainment industry, as the subject of this qualitative study. Author has conducted an observation and in-depth interview, as well as seen interactions in his daily life and on social media. Hilbram Dunar was chosen because author sees him as one of the public figures that stays consistent with his work, as well as reputable throughout his career.

\section{RESULTS AND DISCUSSION}

\section{Profile of the Informant}

The subject of this study is Hilbram Dunar, whom author observed over the course of a year in terms of his daily activities, the way he performed his work as a public figure, the way he dressed and how he built interactions on his social media. Author views that the subject has the right criteria to be highlighted in this study because he is one of the public figures in the entertainment industry that has succeeded in maintaining his good image.

The following is his career background (wikipedia, 2013): Hilbram Dunaris a TV host, radio announcer, master of ceremonies, and entertainer from Indonesia. He is widely known as the host on some of the shows on local TV stations such as the Grand Prix Formula 1 shows on RCTI, MNCTV, Global TV, and tvONE, Mario Teguh Golden Ways and its talk show on Metro TV. His name was making its fame in the entertainment industry since he became an announcer at MS Tri FM, Jakarta from 1996 to 1998 . He then also hosted some radio shows such as the Afternoon Prime Time (2002 to 2004) and the Morning Prime Time (2004 to 2005) on Hard Rock FM. After a vacuum of being a radio announcer in 2006, he then joined the Cosmopolitan radio station to host the show Breakfast Club Cosmopolitan FM in 2008. He started hosting another radio show SAPA PAGI, a morning prime time show, on 97.5 FM Motion Radio Jakarta in 2010 .

After a successful career in the radio industry, Hilbram Dunar also thrived in the TV industry. His debut dated back to 2000 when he became one of the quiz hosts for a Formula 1 show on RCTI, with Feni Rose, Yane Ardian, andVenita Daben. In the end of 2001, the establishment year of TransTV, Hilbram was trusted to host the show Trans Tune In, Kisi-Kisi, and Santapan Pagi, together with Venita Daben. When TPI broadcasted several sport shows in 2001, Hilbram was chosen to be the host. Some of the shows include: the Formula 1 (withNico Siahaan, Charles Bonar Sirait, Nira Stania, and Feni Rose), theLiga Italia Serie-A (with Feni Rose), the La Liga Espana, andthe Women Volley Ball World Grand Prix.

Today, Hilbram Dunar also becomes an ambassador and a commercial star of Bodrex, a local medicine brand. In addition to his success as TV and 
radio host, Hilbram Dunar is also a successful M.C. for different events, both formal and semi-formal. Hilbram Dunar also becomes a book writer. The title of his latest book is "Main Hati - Karena Cinta Tidak Bisa Mati Tapi Bisa Pergi kalau Tidak Dijaga Sepenuh hati", which roughly translates into Involve Feelings - Because Love Can Never Die, but Can Slip If Not Guarded Wholeheartedly. This book contains a collection of short stories regarding love titled 'Plastic Heaven - It's Not Love If Tears Don't Fall Because Of Incredible Pain or Utmost Happiness". He also has the column "Ask Expert" on love on http://id.she.yahoo.com/tanyaahli/. He also performed as a speaker on a number of seminars, and a teaching staff at some institutions offering public speaking courses. In 2013, he was appointed by one of the political parties as their public speaking and communication expert.

\section{Image-Building of the Informant}

As a public figure in the entertainment world, the informant wishes to be known as someone who is able to add value to the public and give quality entertainment. He laid particular stress on quality because he does not want to be known as a public figure who wishes just to become a ridicule on TV, without addition to value on the shows airing him for public consumption.

"I'd like to be known as Hilbram Dunar who could add value to the society, as well as entertain with quality. The quality here does not have to be in a serious manner, but, well at least not without aim such as slipping down just to joke around...something smart...meaningful.",

The informant wishes his audiences to see an intelligent public figure, a humble figure when they look at him.

"I've started out since I was in the university. I needed cash and I became an announcer at the radio campus of Trisakti University, or known as $M S$ TRI. The show was casual but smart. I had to present the latest information and news. Since it was a radio, the image needed to be maintained... That also applied when I moved to Hard Rock FM. There were the dos and the don'ts."

The informant started to be more concerned about his self image and the image he had to convey as a radio announcer when he started working at Hard Rock FM Jakarta. He had to project the appropriate figure matching the radio segment, which is the urban Jakartans who are modern, dynamic, in the upper-middle class, care about trends and the latest lifestyle.

"My radio audience at the time was the hip Jakartans. They had money and liked to have fun, went clubbing and to cafes. I had to represent a similar image. I couldn't wear inappropriate or outdated jeans, I couldn't be seen in public with an image that didn't represent our audience. For instance, I needed to look proper when I went to malls in the outskirt areas... although in reality I was not like that entirely. The bottomline is to keep up with the lifestyle."

\section{Personal Branding}

The competition in the entertainment industry is getting fiercer. There are always the newcomers, which also apply in the informant's field of work as a TV presenter and radio announcer. However, the informant stated that if he can maintain consistency and quality in his work and appear different, one of a kind, then he can survive in his profession.

"There are always competitors... a lot of them...many are good-looking, well-spoken, and many more...but in average, all of us are more or less the same, then everyone's career will be over...I realize that there has to be something specific, something special about me...that was a process until it's finally shaping up."

Over the course of the informant's career, he already found what differentiates him from the rest of his collegues in the given profession. He is a tactical, intelligent, warm, sometimes philosophical and romantic when he host a show, and his clever ability to play with words makes him special in what he does, especially after he became a host on the show Mario Teguh The Golden Ways (Metro TV), with Mario Teguh, the infamous motivator, which strengthen the informant's personal branding. The informant eventually released two books, love themed, which are consisted of a series of short stories.

"I like to play with philosophical words as the end quote in the end of a show that I host more so after I became the host of Mario Teguh Golden Ways. It is necessary to be presentable, smart, and sympathetic in general... and I happened to love playing with words...I always liked to write since then, but I keep it to myself or on my blog. It never occured to me to pour it in a book. Luckily, an offer came and finally I published the books, about love... a novel with short stories in it...even though they were not based on my own experience, but I kept the quality of the stories tasteful and in line with my image."

With regard to appearance, the informant emphasized on being neat, representative and mature. He wants to appear as a charismatic yet casual figure.

"In essence, I'd like to appear mature, not too look like youths nowadays. Sophisticated...in line with my image... and my hair...it has to have clean cut. And I also care about skin hygiene. If we 
appreciate the way we look, it means we appreciate what we see in the mirror."

In the informant's day to day life as a husband and a father of two, his personal branding as a family man should also be enforced with the support of the family. This is not just the responsibility of the informant alone, but his family should also act and behave in accordance with the informant's image.

"My family and I often got featured in family magazines. They took our picture as a family of four and according to the reporters, my family is a good fit for the image and representative to be portrayed as a harmonious family. I'm blessed with a wife who behave accordingly every single day and her image as a smart lady and a great mom, that's how she truly is. My children are also active and bright. I'm a happy man blessed with such an amazing family, which is in line with the image that we've built. They helped create the Hilbram Dunar who is full of love. My wardrobe is also managed by my wife because she knows best what is current. And the closeness we have with our children, the aura shines. Now, if the media wants to feature me, it's all about life at home and children...My wife and children are good in knowing the boundaries I have as a husband and the boundaries for themselves as well."

\section{Reputation Marketing}

Although the career that the informant has built since 1996 to date has experienced ups and downs, it shapes the informant's reputation. The reputation that is attached to himself as a presenter, M.C. and radio announcer who has good image in the public eyes. So far, there has been none incident or news that would cost him his reputation. The informant claimed that he takes care of the reputation simply because it is the reality he lives in, not just an image he tries to fabricate.

"None, there has been no news or whatsoever that is damaging. Just walk the talk. Not an image-building, but it is just how it is."

According to the informant, image-building is a fabrication to portray something good while it is not. On the contrary, the informant tries to keep everything real by avoiding matters that may ruin his reputation

"Image-building to me is like someone tries to look good, while he is not. Essentially, it is not about being pretentious...you should walk the talk because being a public figure is a risky job."

The informant is now the brand ambassador of Bodrex, a medicine for headache, for all of its variants, replacing the former, Dede Yusuf. In addition, the Ministry of Energy and Mineral Resources of the Republic of Indonesia also appointed him as the representative to promote public awareness on domestic accidents and fires. According to him, he was chosen as brand ambassador because of his image and appearance.

"Yes, I become the brand ambassador of Bodrex and all of its variants. Also to help the Ministry of Energy and Mineral Resources with increasing public awareness regarding domestic accidents and fires. Maybe they chose me because I'm good-looking...eheehhe...no, not really. I think it's because of my image. Well, in the case of Bodrex, perhaps they need a guy matching their target market."

The informant's image as a family man also became a factor of him being appointed by the National Population and Family Planning Board $(\mathrm{BKKBN})$ to be involved in a drama talkshow portraying the ideal family in Indonesia.

"As part of the program of BKKBN, I become the host and play a role as an ideal family to spread awareness in all parts of Indonesia. Ameen. That means the harmonious image and reputation of my family and mine has led me to getting this project."

The informant also does not randomly accept just any job for the sake of his career as a public figure. He is selective in choosing work. The work he accepts should never damage the positive image of himself. As of now, not only is he a presenter, but also a writer and a communication expert for several political parties.

"Currently I'm also a presenter of Mario Teguh Golden Wayus. Surely they would expect I can represent the image of the show: sympathetic and charismatic. And I shall never 'slip' in my day to day routines because my reputation is at stake. I still write until now, about love. Although I can express myself more freely there, but I stick to the principles. Classy. It's merely my story, it's not about me. And now I'm appointed as the board of communication experts of political parties. So yes, I have a lot to work on. In principle, as long as the criteria of jobs are not damaging, meaning positive in my vocabulary, I will take it."

\section{Reputation Marketing in the Age of the Internet}

In the age of the internet today, the social media usage growth in is like two sides of a coin, which is either: beneficial for building reputation or damaging the reputation. The informant is fully aware that he cannot use his social media accounts mindlessly. He keeps an eye on what he writes, photos that he uploads and so on.

"I'm the type of person that think first before tweeting...There are many public figures whose reputation is tarnished because of what they tweet...I often only talk about soccer on twitter, or 
F1 simply because I'm a presenter of related shows. I don't tweet about mindless doubts nor respond to what's hot. It's enough for me to touch upon that within my appropriate circles, but never on social media...particularly tweet war...I never let my self be provoked by the likes... Well the age of the internet comes with its benefits and dangers."

The benefit that the informant has reap from the age of the internet is the ability to promote, particularly the programs that he hosts or the books that he writes.

"I can put information on the shows or promote my books, sometimes I also host contests with hastags for fun about the content of my books...or about the topics on the radio shows. The fans can also interact directly with me, although I don't respond to all mentions on twitter, but I still use language that is polite to them, and I think it is good to maintain good relationships with the fans."

\section{CONCLUSION}

This study shows the importance of building a reputation for the sake of career advancement of a public figure. However, there is no particular claim regarding what kind of image that the public prefers. A public figure must comprehend what is expected by their audience segments and what they like or dislike. Reputation is built by image and it correlates with personal brandingthat is appropriate by the public figure, for the survival of his career in the entertainment industry that is incredibly competitive. To be sustainable, the image of a public figure should be backed by the way he behaves in his daily life, the way he communicates, the way he looks visually and the way he performs in his work.

In the age of the internet today, a public figure must not only build his image and reputation in the real world, but also in the digital world. He should be careful with what he writes or upload, i.e. photos, because the public can become opiniated as a result of what the public figure does with his social media.

Reputation is crucial for the career of a public figure, and good image is not easy to maintain. The implementation of reputation marketing for a public figure works in the same way as the selling of a product, which is a means to generate profit. A public figure has become a commodity in which good image will bring positive impact to the advancement of his career. A positive reputation is a valuable asset for public speakers to maintain their careers and public's fondness towards them. For that reason, reputation marketing should also be applicable for individuals, not just corporations.

\section{REFERENCES}

Arruda, W. (2002). An Introduction to Personal Branding, a revolution in the way we manage our careers. A publication of reach communication consulting, inc. $\mathrm{p}$. $2-12$

Hana, Lidwina (2013). Politik Indonesia di Era Industri Citra. Accessed on 8 November 2013 from http://www.umn.ac.id/home/viewarticle/ _Politik_Indonesia_di_Era_Industri_Citr a

Keitzmann, J.H., Hermkens,K., MbBharty, I.P., \& Silvestre, B.S (2011). Social Media? Get serious! Understanding the functional building blocks of social media. Business Horizon, 241-251

Koentjaraningrat (1999). Metode-Metode Penelitian Masyarakat. PT. Gramedia Pustaka Utama

Kohen, P. (2011). How celebrities use social media to buid their brand. Accessed on 10 November 2013 fromhttp://socialmediatoday.com/philcoh en4/1541596/how-celebrities-use-socialmedia-build-their-brand

Koku, P.S (1995). On bizarreness in the entertainment industry, Journal of service marketing, VOL.9, Number 4 p.19-30

Kriyantono, R. (2006). Teknik praktis riset komunikasi. Jakarta: Prenada Media

Marconi, Joe. (2002). Reputation Marketing: Building and Sustaining Your Organization's Greatest Asset. McGrawHill, USA

Montoya, P \& Vandehey, T. (2003). The brand called you: create a personal brand that wins attention and grows your business. McGraw-Hill

Nawawi,H. (1995). Metode penelitian sosial:dasar dasar dan aplikasinya. Jakarta:PT Rajawali Pers

Rakhmat, Jalaluddin. (2007). Metode Penelitian Komunikasi. PT. Remaja Rosda Karya, Bandung

Schawbel, D. (2009). Me 2.0: Build a powerful brand to achieve career success. Kaplan publishing, inc, New York

Shepard, I.D.H. (2005). From Cattle and Coke to Charlie: Meeting the Challenge of self marketing and Personal Branding, Journal of Marketing Management, VOL 21 p.589-606 
Sutojo, Siswanto \& E Jhon Aldridge (2004). Good Corporate Governance, Jakarta, PT. Damar Mulia Pustaka

Wikipedia (2013). Hilbram Dunar. Accessed on 11 November 2013 from
http://id.wikipedia.org/wiki/Hilbram_Du nar

Wimmer, Roger D. \& Joseph R. Dominick. (1991). Mass Media Research: An Introduction. $3^{\text {rd }}$ Ed. Wadsworth Publishing Company, Belmont California 